Pesq. Vet. Bras. 35(6):552-556, junho 2015

DOI: $10.1590 / \mathrm{S} 0100-736 \mathrm{X} 2015000600011$

\title{
Identification and antimicrobial resistance of members from the Enterobacteriaceae family isolated from canaries ${\text { (Serinus canaria })^{1}}^{1}$
}

\author{
Ruben V. Horn ${ }^{2 *}$, William M. Cardoso ${ }^{2}$, Elisângela S. Lopes², Régis S.C. Teixeira², \\ Átilla H. Albuquerque ${ }^{2}$, Roberta C. Rocha-e-Silva², Débora N. Machado ${ }^{2}$ \\ and Windleyanne G.A. Bezerra ${ }^{2}$
}

\begin{abstract}
Horn R.V., Cardoso W.M., Lopes E.S., Teixeira R.S.C., Albuquerque A.H., Rochae-Silva R.C., Machado D.N. \& Bezerra W.G.A. 2015. Identification and antimicrobial resistance of members from the Enterobacteriaceae family isolated from canaries (Serinus canaria). Pesquisa Veterinária Brasileira 35(6):552-556. Laboratório de Estudos Ornitológicos, Faculdade de Veterinária, Universidade Estadual do Ceará, Av. Paranjana 1700, Fortaleza, CE 60740-000, Brazil. E-mail: rubenhorn@hotmail.com

The Enterobacteriaceae family contains potentially zoonotic bacteria, and their presence in canaries is often reported, though the current status of these in bird flocks is unknown. Therefore, this study aimed to identify the most common genera of enterobacteria from canaries (Serinus canaria) and their antimicrobial resistance profiles. From February to June of 2013, a total of 387 cloacal swab samples from eight domiciliary breeding locations of Fortaleza city, Brazil, were collected and 58 necropsies were performed in canaries, which belonged to the Laboratory of Ornithological Studies. The samples were submitted to microbiological procedure using buffered peptone water and MacConkey agar. Colonies were selected according to their morphological characteristics on selective agar and submitted for biochemical identification and antimicrobial susceptibility. A total of 61 isolates were obtained, of which 42 were from cloacal swabs and 19 from necropsies. The most isolated bacteria was Escherichia coli with twenty five strains, followed by fourteen Klebsiella spp., twelve Enterobacter spp., seven Pantoea agglomerans, two Serratia spp. and one Proteus mirabilis. The antimicrobial to which the strains presented most resistance was sulfonamides with $55.7 \%$, followed by ampicillin with $54.1 \%$ and tetracycline with $39.3 \%$. The total of multidrug-resistant bacteria (MDR) was 34 (55.7\%). In conclusion, canaries harbor members of the Enterobacteriaceae family and common strains present a high antimicrobial resistance rate, with a high frequency of MDR bacteria.
\end{abstract}

INDEX TERMS: Antimicrobial resistance, Enterobacteriaceae, canaries, Serinus canaria, Gram negative bacteria, Passeriformes, Escherichia coli, multidrug-resistance.

RESUMO.- [Identificação e resistência antimicrobiana de membros da família Enterobacteriaceae isolados de canários (Serinus canaria).] A família Enterobacteriaceae possui bactérias com potencial zoonótico e a presença destas bactérias em canários é relatada na literatura, porém a realidade dos plantéis de criadores de canários é desconhecida. Portanto, este trabalho teve como objetivo isolar

\footnotetext{
${ }^{1}$ Received on September 22, 2014.

Accepted for publication on March 10, 2015.

${ }^{2}$ Laboratório de Estudos Ornitológicos, Faculdade de Veterinária, Universidade Estadual do Ceará (UECE), Avenida Paranjana 1700, Fortaleza, CE 60740-000, Brazil. *Corresponding author: rubenhorn@hotmail.com
}

enterobactérias de canários belga (Serinus canarius) com o intuito de conhecer os gêneros mais comuns nestas aves e suas respectivas resistências a antimicrobianos. De fevereiro a junho de 2013 foram coletadas 387 amostras de swabs cloacais de canários de oito propriedades da cidade de Fortaleza, Brasil e de 58 necropsias de aves do acervo próprio do Laboratório de Estudos Ornitológicos. As amostras foram submetidas a isolamento microbiológico utilizando-se água peptonada e ágar MacConkey. As colônias foram selecionadas de acordo com suas características morfológicas nas placas, submetidas à tipificação bioquímica para identificação e ao teste de sensibilidade a antimicrobianos. Fo- 
ram isoladas 61 cepas, sendo 42 de suabes cloacais e 19 de necropsias. A bactéria mais isolada foi Escherichia coli com vinte e cinco cepas, seguida por catorze Klebsiella spp., doze Enterobacter spp., sete Pantoea agglomerans, duas Serratia spp. e uma cepa de Proteus mirabilis. As cepas apresentaram maior resistência a sulfonamidas com 55,7\%, seguidas por ampicilina com 54,1\% e tetraciclina com 39,3\%. Além disso, o total de cepas resistentes a múltiplas drogas (RMD) foi $34(55,7 \%)$. Portanto, conclui-se que os canários albergam enterobactérias e que as cepas apresentam alto índice de resistência a antimicrobianos, com alta frequência de cepas RMD.

TERMOS DE INDEXAÇÃO: Resistência antimicrobiana, Serinus canaria, canários, enterobactérias, multirresistência.

\section{INTRODUCTION}

Birds of the Passeriformes order usually do not harbor a large quantity of microorganisms in their intestinal tract, however, birds are susceptible to a variety of bacterial infections (Joseph 2003), such as those caused by pathogens of the family Enterobacteriaceae. These, however are considered secondary and the presence of predisposing factors are necessary for the infection to occur. Several genera of this family have been reported causing different diseases in passerines, such as: Escherichia coli, Salmonella spp., Citrobacter spp., Yersinia pseudotuberculosis and Klebsiella spp. (Macwhirter 1994).

The Enterobacteriaceae is a large family of Gram-negative bacteria (Quinn et al. 1994), also called enterobacteria, which do not belong in the normal digestive microbiota of granivorous passerines, and their presence in clinically healthy birds are associated with direct contact with man (Asterino 1996). Similar to all other vertebrates, birds are susceptible and can also transmit enteropathogens to humans and, surprisingly, there are few comprehensive surveys done for wild and most domesticated birds (Reed et al. 2003). There are reports of human infections caused by E. coli and $S$. Typhimurium transmitted indirectly by migratory birds belonging to the Passeriformes order (Tsiodras et al. 2008) which, hypothetically, suggest that the transmission of these pathogens by passerines when maintained in the home environment can occur. Also, several outbreaks of human salmonellosis have been associated with foodborne contamination by passerines (Kapperud et al. 1998, Alley et al. 2002).

The canary (Serinus canaria) belongs to the Passeriformes order and a member of the Fringillidae family. These are small birds (50 to $120 \mathrm{~mm}$ ) with a curve, thick and conic beak, often light colored, though some varieties present a thick beak tip (Jackson et al. 2003, Gismondi 1995). The canary is common in all continents worldwide, though primarily in Europe the bird has become a common companion in the home as well as for competitive purposes, in which breeders compete their birds in three categories: song, color and type (Cattarossi et al. 2013). Due to the absence of studies of the fermentative Gram-negative microbiota of these birds and their importance in the Brazillian home environment, this study aimed to identify the most common Enterobacteriaceae genera and to characterize the antimicrobial resistance of the strains isolated from canaries (Serinus canaria) of domiciliary breeding locations in Fortaleza city, Brazil.

\section{MATERIALS AND METHODS}

From February to June 2013 a total of 387 cloacal swab samples from eight domiciliary breeding locations and 58 necropsy samples, performed as a pool of liver and intestines of each canary, were collected. The cloacal swab samples were collected from each location and submitted to the Laboratory of Ornithological Studies (LABEO) at the State University of Ceará for the microbiological procedure. Each bird sampled was visually evaluated for the presence of clinical signs commonly associated with enterobacteria infection, such as: diarrhea, ruffled feathers, dyspnea and weight loss. The dead birds analyzed belonged to the personal collection of LABEO, and the carcasses were maintained frozen at $-20^{\circ} \mathrm{C}$ until sampling was performed. The necropsies were performed close to the Bunsen burner, aseptically and using sterile equipment to prevent contamination.

Cloacal swabs and necropsy samples were placed in tubes containing buffered peptone water broth and incubated at $37^{\circ} \mathrm{C}$ for $24 \mathrm{~h}$. A loopful was collected from each tube, streaked in plates containing MacConkey agar and incubated in the same previous conditions. Colonies were selected according to their morphological characteristics and from each plate, at least one was selected for each morphological profile, submitted to Triple-Sugar-Iron (TSI) agar in order to differentiate from non-fermenter bacteria following biochemical identification (Quinn et al. 1994) using conventional tests, such as: motility, indole production, lysine decarboxylation, ornithine descarboxylation, Voges-Proskauer, methyl red, citrate, malonate and carbohydrates fermentation. Once identified, every member of the Enterobacteriaceae family was stored in nutrient agar for the resistance analysis.

The antimicrobial susceptibility test was performed using the disk diffusion method with the following discs of respective concentrations: ampicillin $(10 \mu \mathrm{g})$, nalidixic acid $(30 \mu \mathrm{g})$, ceftiofur $(30 \mu \mathrm{g})$, enrofloxacin $(5 \mu \mathrm{g})$, sulfazotrim (trimethoprim + sulfamethoxazole) $(25 \mu \mathrm{g})$, streptomycin $(10 \mu \mathrm{g})$, neomycin $(30 \mu \mathrm{g})$, polymyxin B (300 U.I.), sulfonamides $(300 \mu \mathrm{g})$, gentamycin $(10 \mu \mathrm{g})$, chloramphenicol $(30 \mu \mathrm{g})$ and tetracycline $(30 \mu \mathrm{g})$. Briefly, the strains were reactivated in BHI broth incubated for $24 \mathrm{~h}$ at $37^{\circ} \mathrm{C}$, then streaked in MacConkey agar and after incubation under the same previous conditions a single colony was selected, homogenized in $2 \mathrm{~mL}$ of saline solution $0.9 \%$ until a 0.5 turbidity in McFarland scale was achieved. Then, an aliquot was collected, distributed equally in a plate containing Mueller-Hinton agar (Himedia ${ }^{\circledR}$ ) and disks containing the antibiotics were added to the medium. After the incubation period, zone diameters were measured and interpreted following the Clinical Laboratory Standards Institute (CLSI 2012) guidelines, also intermediate zone diameters were interpreted as resistant to the respected antimicrobial.

\section{RESULTS}

The total prevalence of enterobacteria found in cloacal swabs of canaries analyzed was $10.85 \%(42 / 387)$ and in necropsies was $32.76 \%(19 / 58)$; the results are presented in Table 1. The most frequent bacteria isolated from cloacal swabs was Escherichia coli (14/387), followed by Enterobacter spp. (11/387) and Klebsiella spp. (9/387). Other bacteria less frequently isolated were Pantoea agglomerans (5/387), Serratia spp. (2/387) and Proteus mira- 
Table 1. Absolute and relative frequencies of enterobacteria isolated from cloacal swabs and necropsy samples of canaries (Serinus canaria) from Fortaleza, Brazil

\begin{tabular}{|c|c|c|c|c|c|c|}
\hline \multirow[t]{2}{*}{ Enterobacteria } & \multicolumn{2}{|c|}{$\begin{array}{l}\text { Swabs } \\
(n=387)\end{array}$} & \multicolumn{2}{|c|}{$\begin{array}{l}\text { Necropsies } \\
(n=58)\end{array}$} & \multicolumn{2}{|c|}{$\begin{array}{c}\text { Total } \\
(n=445)\end{array}$} \\
\hline & $\mathrm{n}$ & $\%$ & $\mathrm{n}$ & $\%$ & $\mathrm{n}$ & $\%$ \\
\hline Escherichia coli & 14 & 3,62 & 11 & 18,97 & 25 & 5,62 \\
\hline Enterobacter spp. & 11 & 2,84 & 1 & 1,72 & 12 & 2,7 \\
\hline Klebsiella spp. & 9 & 2,32 & 5 & 8,62 & 14 & 3,15 \\
\hline Pantoea agglomerans & 5 & 1,29 & 2 & 3,45 & 7 & 1,57 \\
\hline Serratia spp. & 2 & 0,52 & 0 & - & 2 & 0,45 \\
\hline Proteus mirabilis & 1 & 0,26 & 0 & - & 1 & 0,22 \\
\hline Total & 42 & 10,85 & 19 & 32,76 & 61 & 13,71 \\
\hline
\end{tabular}

formed in the sequence and a strain of Escherichia coli was isolated. Of the 384 negative birds, 26 presented diarrhea.

The antimicrobial susceptibility test results are demonstrated in Table 2. The antimicrobial to which strains presented the most frequent resistance was sulfonamides with $55.7 \%$, followed by ampicillin with $54.1 \%$ and tetracycline with $39.3 \%$. More than $50 \%$ of $E$. coli strains presented resistance to sulfonamides (64\%), but a high resistance rate was also observed to tetracycline (48\%), sulfazotrim (sulfamethoxazole+trimethoprim) (44\%), streptomycin (40\%) and chloramphenicol (36\%). The genus Enterobacter presented a high resistance rate only to

Table 2. Percentage of Enterobacteriaceae strains isolated from canaries (Serinus canaria) resistant to antimicrobials

\begin{tabular}{|c|c|c|c|c|c|c|c|c|c|c|c|c|c|c|}
\hline & \multicolumn{2}{|c|}{ E. coli } & \multicolumn{2}{|c|}{ Enterobacter sp. } & \multicolumn{2}{|c|}{ Klebsiella sp. } & \multirow{2}{*}{\multicolumn{2}{|c|}{$\begin{array}{c}\text { Pantoea } \\
\text { agglomerans }\end{array}$}} & \multicolumn{2}{|c|}{ Serratia sp. } & \multirow{2}{*}{\multicolumn{2}{|c|}{$\begin{array}{c}\text { Proteus } \\
\text { mirabilis }\end{array}$}} & \multicolumn{2}{|c|}{ Total } \\
\hline & \multirow[t]{2}{*}{$\mathrm{n}=25$} & \multirow[t]{2}{*}{$\%$} & \multirow[t]{2}{*}{$\mathrm{n}=12$} & \multirow[t]{2}{*}{$\%$} & \multirow[t]{2}{*}{$\mathrm{n}=14$} & \multirow[t]{2}{*}{$\%$} & & & \multirow[t]{2}{*}{$\mathrm{N}=2$} & \multirow[t]{2}{*}{$\%$} & & & \multirow[t]{2}{*}{$\mathrm{N}=61$} & \multirow[t]{2}{*}{$\%$} \\
\hline & & & & & & & $\mathrm{n}=7$ & $\%$ & & & $\mathrm{~N}=1$ & $\%$ & & \\
\hline AMP & 4 & 16 & 8 & 66,7 & 14 & 100 & 5 & 71,4 & 2 & 100 & 0 & 0 & 33 & 54,1 \\
\hline NAL & 3 & 12 & 1 & 8,3 & 2 & 14,3 & 0 & 0 & 0 & 0 & 1 & 100 & 7 & 11,5 \\
\hline CTF & 0 & 0 & 0 & 0 & 1 & 7,1 & 0 & 0 & 0 & 0 & 0 & 0 & 1 & 1,6 \\
\hline SUT & 11 & 44 & 1 & 8,3 & 3 & 21,4 & 3 & 42,9 & 0 & 0 & 0 & 0 & 18 & 29,5 \\
\hline STR & 10 & 40 & 4 & 3,3 & 5 & 35,7 & 1 & 14,3 & 0 & 0 & 1 & 100 & 21 & 34,4 \\
\hline NEO & 4 & 16 & 1 & 8,3 & 3 & 21,4 & 3 & 42,9 & 0 & 0 & 1 & 100 & 12 & 19,7 \\
\hline SUL & 16 & 64 & 4 & 3,3 & 8 & 57,1 & 4 & 57,1 & 1 & 50 & 1 & 100 & 34 & 55,7 \\
\hline GEN & 1 & 4 & 0 & 0 & 1 & 7,1 & 0 & 0 & 0 & 0 & 0 & 0 & 2 & 3,3 \\
\hline CLO & 9 & 36 & 0 & 0 & 0 & 0 & 0 & 0 & 0 & 0 & 1 & 100 & 10 & 16,4 \\
\hline ENO & 1 & 4 & 0 & 0 & 2 & 14,3 & 1 & 14,3 & 0 & 0 & 0 & 0 & 4 & 6,6 \\
\hline TET & 12 & 48 & 2 & 16,7 & 6 & 2,9 & 3 & 42,9 & 0 & 0 & 1 & 100 & 24 & 39,3 \\
\hline POL & 1 & 4 & 1 & 8,3 & 0 & 0 & 0 & 0 & 0 & 0 & $1^{*}$ & $100 *$ & 2 & 3,3 \\
\hline
\end{tabular}

$\overline{\mathrm{AMP}}=$ ampicillin, $\mathrm{NAL}=$ Nalidixic acid, $\mathrm{CTF}=$ ceftiofur, $\mathrm{SUT}=$ Sulfazotrim (Sulfamethoxazole+trimethopr im), STR = streptomycin, NEO = neomycin, SUL = sulfonamides, GEN = gentamycin, CLO = chloramphenicol, ENO = enrofloxacin, TET = tetracycline, $\mathrm{POL}=$ polymyxin B. ${ }^{*}$ Proteus spp. are naturally resistant to polymyxin B.

Table 3. Multidrug-resistant (MDR) enterobacteria isolated from canaries (Serinus canaria)

\begin{tabular}{cc}
\hline No. of antibiotics & No. of resistant strai \\
\hline At least 1 & $53(83.88)$ \\
$>1$ & $34(55.74)$ \\
$>2$ & $30(49.18)$ \\
$>3$ & $23(37.70)$ \\
$>4$ & $14(22.95)$ \\
$>5$ & $9(14.75)$ \\
$>6$ & $4(6.56)$ \\
$>7$ & $1(1.64)$ \\
$>8$ & $0(0)$
\end{tabular}

bilis $(1 / 387)$. The most frequent bacteria isolated from necropsy samples was Escherichia coli (11/58), followed by Klebsiella spp. (5/58), Pantoea agglomerans (2/58) and Enterobacter spp. (1/58). No bird presented more than one enterobacteria in the selective agar plates, though occasionally, some presented besides the enterobacteria, a non-fermenter Gram-negative bacteria, which was identified and discarded in the TSI agar.

From the 61 birds that were positive for some enterobacteria, only 11 presented diarrhea, of which 8 were from cloacal swabs and 3 were from necropsy. From these three, one presented negative in the swab and after two days from sampling was found dead in the cage. Necropsy was per- ampicillin (66.7\%), while the genus Klebsiella presented a $100 \%$ resistance rate to ampicillin and a high resistance rate to sulfonamides (57.1\%). The Pantoea agglomerans strains presented high resistance rate to ampicillin (71.4\%), to sulfonamides (57.1\%), to neomycin (42.9\%), to sulphametoxazole+trimethoprim $(42.9 \%)$ and tetracycline (42.9\%). The genus Serratia presented resistance only to ampicillin (100\%) and sulfonamides (50\%), while the only Proteus mirabilis isolated was resistant to nalidixic acid, streptomycin, sulfonamides, chloramphenicol, tetracyline and polymyxin B, to which the genus Proteus is naturally resistant. The total of multidrug-resistant bacteria (MDR) was $34(55.7 \%)$ and the maximum antimicrobials to which a single isolate was resistant was eight, followed by three isolates that were resistant to seven antimicrobials. The Table 3 demonstrates the amount of isolates and antimicrobials to which resistance was observed.

\section{DISCUSSION}

Surveys of Enterobacteriaceae have been performed in several avian species, from which different members of this bacterial family were isolated from birds in captivity belonging to 15 orders (Jones \& Nisbet 1980). The enterobacteria are widely distributed in the environment, in the microbiota of mammals and of some birds (Fudge 2001), however passerines do not possess a functional caeca, or an intesti- 
nal microbiota for the digestion of nutrients, which makes the presence of members of the Enterobacteriaceae family often related to a disease status (Dorrestein 2003).

In this study, the prevalence of enterobacteria was higher in dead birds, than it was in the live ones, which may be explained by the growth that occurs from the moment of death until the carcass was found and frozen. Also, the technique itself may have favored the necropsy results, since large intestinal samples were collected, when compared to swabs which sample a low amount of bacteria present in the cloaca. Another possibility is due to the pathogenic potential that many of these micro-organisms possess, though with the methodology applied these possible infections cannot be confirmed.

Most mammals and some bird species possess Escherichia coli in their normal intestinal flora, since they are colonized at birth and remain with this bacterium during the entire life (Fudge 2001). Passerines, in spite of having a permanent microbiota, may host this bacterium with no symptoms, which have been reported (Jones \& Nisbet 1980), however other authors have reported this microorganisms causing different diseases in passerines (Macwhirter 1994, Dorrestein 2003, Cattarossi et al. 2013). In this study, E. coli was the most frequently isolated bacteria from both dead and live canaries, which may suggest a zoonotic potential, since several other birds in this study were present in home environments and, therefore, in direct contact with the owners. More studies on the virulence of these strains are necessary in order to confirm this hypothesis, since $E$. coli strains with virulence factors have been previously isolated from passerines (Gibbs et al. 2007).

The genera Enterobacter and Klebsiella may cause primary or secondary infections in passerines, sometimes acting as opportunistic pathogens associated or not with viral, parasitic or fungal infections (Joseph 2003). Bacteria from the genus Klebsiella and the species Enterobacter sakazakii have been correlated with the occurrence of high mortality outbreaks in canary flocks, and these microorganisms have been considered as important as Salmonella, Escherichia coli, Listeria spp., Staphylococcus spp. and Pseudomonas (Cattarossi et al. 2013). The genus Serratia may be an opportunistic pathogen in passerines, much like Klebsiella and Enterobacter, however it occurs less frequently and the most common species are $S$. marcescens, S. odorifera, S. rubidae and S. liquefaciens (Fudge 2001). In this study, only one strain of $S$. odorifera and one strain of $S$. liquefaciens were identified, each present in a different sample.

The most important and most frequently reported bacterium in the scientific literature isolated from canaries is Salmonella sp. (Harrington et al. 1975, Panigrahy \& Gilmore 1983, Asterino 1996, Raidal 1998, Fudge 2001, Dorrestein 2003, Madadgar et al. 2009, Rahmani et al. 2011). However, in this study no bacteria from this genus were isolated, which may be explained by the excessive use of antibiotics by the owners and the absence of outbreaks reported in the domiciliary breeding locations visited. The methodology applied may have also hindered the isolation of these bacteria, since it has already been demonstrated that the polymerase chain reaction (PCR) test present a higher positivity rate when compared to the conventional culture for the survey of Salmonella from the feces of pet birds, however with no significant difference between the two tests (Sareyyüpoğlu et al. 2008). Due to the reports in the literature and the importance that this genus represents, control measures must always be applied in order to guarantee the safety of the birds, owners and environment.

The genus Yersinia possess species that cause zoonotic infections, being Y. pseudotuberculosis the most frequently isolated bacterium from the intestines of wild and captive passerines (Quinn et al. 1994). However, this pathogen is more reported during the winter months, when the cold weather benefits the growth of this pathogen and cause outbreaks of yersiniosis (Fudge 2001). Another predisposing factor that favors the occurrence of this infection is the infestation by rodents or wild birds, which may carry this bacterium and disseminate in the environment (Guimarães 2006). The absence of this genus in the studied birds may be explained by the local weather that do not favor the spread of this bacterium and the absence of problems with rodents or wild birds, as reported by the owners.

According to the literature, several members of the Enterobacteriaceae family are known to cause, among other illnesses, intestinal infections, and the main symptom observed in these cases of diseased passerines is diarrhea (Macwhirter 1994, Dorrestein 2003, Guimarães 2006). In this study, however, most $(26 / 37)$ of the canaries that presented diarrhea did not present any enterobacteria, which indicates that different etiologies may be implied, such as gastrointestinal parasites, viral or fungal infections, or food disorders (Joseph 2003).

Elevated antimicrobial resistance have been reported (Gaukler et al. 2009) in E. coli strains isolated from passerines, mainly to ampicillin and to tetracycline, and also the occurrence of MDR strains, which is similar to the findings in this study, however in the previous study the birds were wild, which, theoretically do not have access to significant quantities of antimicrobials. Other authors, in spite the low amount of tested strains, found frequent antimicrobial resistance in strains of Klebsiella and Enterobacter to ampicillin and ceftiofur, which the former agrees with this study, but the latter disagrees (Gibbs et al. 2007); the same authors also reported a low frequency of resistance in Pantoea agglomerans strains, which was different from this study that encountered strains of this species resistant to a maximum of six antibiotics. However, this result may not have a major importance, since this bacterium is more commonly isolated from plants, rarely causing infection in man (De Champs et al. 2000) and with uncertain significance for animals (Quinn et al. 1994). Also, a high resistance rate to antimicrobials has been reported in Salmonella strains isolated from several pet birds, including canaries (Rahmani et al. 2011). In this study, the high resistance rate to antibiotics and the high frequency of MDR enterobacteria isolated from canaries of home environments suggest that the use of antibiotics is elevated and should be controlled. 


\section{CONCLUSIONS}

Canaries (Serinus canaria) host members of the Enterobacteriaceae family and Escherichia coli is the most frequent contaminant.

The enterobacteria strains from these birds present a high resistance rate to antimicrobials, and the emergence of multidrug resistant strains is concerning, since the proximity of these birds and people represents a potential zoonotic risk.

\section{REFERENCES}

Alley M.R., Connolly J.H., Fenwick S.G., Mackereth G.F., Leyland M.J., Rogers L.E., Haycock M., Nicol C. \& Reed C.E.M. 2002. An epidemic of salmonellosis caused by Salmonella Typhimurium DT160 in wild birds and humans in New Zealand. N. Z. Vet. J. 50:170-176.

Asterino R. 1996. Diseases and care of wild passerines, p.956-980. In: Rosskopf W.J. \& Woerpel R.W. (Eds), Diseases of Cage and Aviary Birds. 3rd ed. Williams and Wilkins, Baltimore.

Cattarossi D., Azzara E. \& Catania S. 2013. Clinical and laboratory practice for canaries and true finches. Vet. Clin. North Am., Exotic Anim. Pract. 16:31-46.

CLSI 2012. Performance Standards for Antimicrobial Susceptibility Testing. $22^{\text {nd }}$ Informational Supplement. CLSI document M100-22. Clinical and Laboratory Standards Institute, Wayne, PA.

De Champs C., Le Seaux S., Dubost J., Boisgard S., Sauvezie B. \& Sirot J. 2000. Isolation of Pantoea agglomerans in two cases of septic monoarthritis after plant thorn and wood sliver injuries. J. Clinic. Microbiol. 38:460-461.

Dorrestein G.M. 2003. Diagnostic approaches and management of diseases in captive passerines. Sem. Avian Exotic Pet Medicine 12:11-20.

Fudge A.M. 2001. Diagnosis and treatment of avian bacterial diseases. Sem. Avian Exotic Pet Medicine 10:3-11.

Gaukler S.M., Linz G.M., Sherwood J.S., Dyer N.W., Bleier W.J., Wannemuehler Y.M., Nolan L.K. \& Logue C.M. 2009. Escherichia coli, Salmonella, and Mycobacterium avium subsp. paratuberculosis in Wild European Starlings at a Kansas cattle feedlot. Avian Dis. 53:544-551.

Gibbs P.S., Kasa R., Newbrey J.L., Petermann S.R., Wooley R.E., Vinson H.M. \& Reed W. 2007. Identification, Antimicrobial Resistance Profiles, and Virulence of Members from the Family Enterobacteriaceae from the Feces of Yellow-Headed Blackbirds (Xanthocephalus xanthocephalus) in North Dakota. Avian Dis. 51:649-655.
Gismondi E. 1995. Procedencia e historia, p.12-14. In: Ibid. (Eds), Guia Completa de los Canarios de Color. Editorial de Vecchi, Barcelona.

Guimarães M.B. 2006. Passeriformes (pássaro, canário, saíra, gralha), p.324-337. In: Cubas Z.S., Silva J.C.R., Catão-Dias J.L. (Eds), Tratado de Animais Selvagens. Roca, São Paulo.

Harrington Jr R., Blackburn B.O. \& Cassidy D.R. 1975. Salmonellosis in canaries, Avian Dis. 19:827-829.

Jackson J.A., Bock W.J., Olendorf D., Trumpey J.E. \& Hutchins M. 2003. Grzimek's Life Encyclopedia. Vol.11. 2nd ed. Gale, USA. 616p.

Jones D.M. \& Nisbet D.J. 1980. The gram negative bacterial flora of the avian gut. Avian Pathol. 9:33-38.

Joseph V. 2003. Infectious and parasitic diseases of captive passerines. Sem. in Avian Exotic Pet Medicine 12:21-28.

Kapperud G., Stenwig H. \& Lassen J. 1998. Epidemiology of Salmonella Typhimurium 0:4-12 infection in Norway. Am. J. Epidemiol. 147:774782.

MacWhirter P. 1994. Passeriformes, p.1172-1199. In: Ritchie B.W., Harrison G.J. \& Harrison L.R. (Eds), Avian Medicine: principles and application. Wingers Publishing, Lake Worth, Florida, USA.

Madadgar O., Salehi T.Z., Ghafari M.M., Tamai I.A., Madani S.A. \& Yahyareyat R. 2009. Study of an unusual paratyphoid epornitic in canaries (Serinus canaria). Avian Pathol. 38:437-441.

Panigrahy B. \& Gilmore W.C. 1983. Systemic salmonellosis in an African gray parrot and salmonella osteomyelitis in canaries. J. Am. Vet. Med. Assoc. 183:699-700.

Quinn P.J., Carter M.E., Markey P.K. \& Carter G.R. 1994. Enterobacteriaceae, p.209-236. In: Ibid. (Eds), Clinical Veterinary Microbiology. Wolfe Publishing, London.

Rahmani M., Peighambari S.M., Yazdani A. \& Hojjati P. 2011. Salmonella infection in birds kept in parks and pet shops in Tehran, Iran. Int. J. Vet. Res. 5:145-148.

Raidal S.R. 1998 Salmonellosis in two canary (Serinus canaria) flocks. Aust. Vet. Pract. 28:67-70.

Reed K.D., Meece J.K., Henkel J.S. \& Shukla S.K. 2003. Birds, migration and emerging zoonoses: West Nile virus, Lyme disease, influenza A and enteropathogens. Clin. Med. Res. 1:5-12.

Sareyyüpoğlu B., Çelik ok A., Cantekin Z., Yardimci H., Akan M. \& Akçay A. 2008. Polymerase Chain Reaction detection of Salmonella spp. in fecal samples of pet birds. Avian Dis. 52:163-167.

Tsiodras S., Kelesidis T., Kelesidis I., Bauchinger U. \& Falagas M.E. 2008. Human infections associated with wild birds. J. Infect. 56:83-98. 